\title{
Studies on the maintenance of fertilizing spermatozoa in the hen's oviduct
}

\author{
Kousaku TanaKa and Osamu Koga \\ (Faculty of Agriculture, Kyushu University, Fukuoka-shi) \\ (Received for Publication on February 5, 1971)
}

The domestic hen maintains fertility for long periods after a single mating or artificial insemination (A.I.). Physiological conditions in the reproductive tract of the hen must be such as to maintain the spermatozoa in a functional state. Mrmura (1939) ${ }^{12}$ and Van Drimmelen (1946) ${ }^{29)}$ observed that the spermatozoa become rapidly distributed throughout the oviduct after A.I. and they disappear long before production of fertile eggs ceases. Allen and Grigg (1957) ${ }^{1}$ ) estimated from the radioactivity of ${ }^{32} \mathrm{P}$-labelled spermatozoa that a small but significant number of spermatozoa reached the infundibulum 1 hour after intravaginal A.I.

VAN Drimmelen $(1946)^{23}$ identified sperm-containing crypts in the chalaziferous region of the infundibulum (the so-called 'spermnest') after intraperitoneal A.I. FujI and TAMURA $(1963)^{91}$ found spermatozoa in the uterovaginal glands as well as in the infundibulum following intravaginal A.I. and they considered both the uterovaginal glands and the infundibular glands as storage sites. In the extensive studies on the distribution of spermatozoa in the oviduct

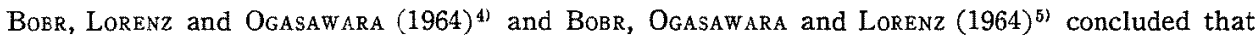
the uterovaginal glands, not the infundibular glands, are the normal residence sites for spermatozoa after copulation or intravaginal A.I. OGASAWARA, LORENZ and BOBR (1966) ${ }^{15)}$ sug. gested that the uterovaginal glands are selective, so that, together with the junction itself, abnormal or handicapped spermatozoa rarely reach the site of fertilization. Later VAN KREY, Ogasawara and Lorenz $(1966)^{24)}$ and LoRenz and Ogasawara $(1968)^{11}$ reported that intramagnal or intrauterine A.I. leads to a higher incidence of early mortality, severe retardation and other abnormalities of the embryo.

\section{Materials and Methods}

White Leghorn roosters, young pullets and yearling hens in active egg production were used. Semen was collected as clear as possible from eight to ten roosters by the one-man technique (Bogdonoff and SHAFFner, 1954') diluted 1.5 times with a phosphate buffer (WILcox and SHAFFnER, 1958 ${ }^{2 n}$ ) containing 2,000 $\mu \mathrm{g}$ dihydrostreptomycin sulfate and $400 \mu \mathrm{g}$ oxytetracycline hydrochloride per $\mathrm{m} l$ and held at $5^{\circ} \mathrm{C}$ in a jar. The amount of semen deposited in the oviduct was $0.1 \mathrm{~m} l$ and in most cases hens that had soft-shelled eggs in the uterus were used for the surgical and normal A.I. Eggs laid following A.I. or treatments were incubated for 4 or 5 days and examined for embryonic development.

Incubation of spermatozoa in various regions of oviduct

For the operation the feathers were plucked from the abdomen and tincture of iodine was applied entirely on the abdominal area. Care was taken to have all instruments, glasswares, 
absorbent cotton and surgical threads sterilized. An incision approximately 4 to $6 \mathrm{~cm}$ long, depending on the site of ligation, was made on the left side of the abdomen along the midline. After exposure of the oviduct, the designated site was ligated with surgical thread about $15 \mathrm{~cm}$ long (J.I.S. No. 6, soft type) which was left in the abdominal cavity without cutting. In the case of the ligation of uterus and vagina, the soft-shelled egg in the uterus was removed by intramuscular injection of posterior pituitary extraction ( 5 oxytocin i.u. per hen) and a couple of the threads was used for the ligation. Semen was injected by a hypodermic syringe through the oviduct wall, except that intravaginal A.I. was done through the cloaca, using a syringe with an extension tube similar to that used by PARKer, MCKenzIE and Kempster (1942) ${ }^{17)}$.

The thread placed on the oviduct was carefully removed 2 days after incubation of spermatozoa in various regions of the oviduct. Due care was taken to minimize the duration of the operation to avoid undue stress on the hen. Eggs laid from the 2nd through 22nd day following removal of the thread and from 4 th through 24 th day following intravaginal A.I. to sham-operated or normal hens were incubated everyday.

Intramagnal A.I. of germ-free vas deferens semen

All instruments, absorbent cotton, etc. were throughly sterilized. Three roosters for each trial were killed and dipped into 5\% saponated cresol solution for several seconds. After removal of the entire skin on the breast and abdomen, tincture of iodine was applied on the skin-removed area and an incisions were made along the edges of the metasternum on both sides of the abdomen. Following penetration of abdominal cavity the posterior part of the vasa deferentia (about $4 \mathrm{~cm}$ long) was isolated and semen in the duct was squeezed out on a watch glass containing $1.5 \mathrm{~m} l$ of sterile phosphate buffer, and throughly mixed. The germ-free diluted vasa semen $\left(2.4-3.0 \times 10^{8}\right.$ sperm per $0.1 \mathrm{~m} l$ per hen) was asceptically injected into the hen's magnum. Eggs laid from 2nd through 22nd day following A.I. were incubated.

Resection of uterovaginal junction

An incision approximately $6 \mathrm{~cm}$ long was made on the left side of the abdomen. Following exposure of the uterus a surgical thread was passed around the uterine wall where it was ligated and tightened in order to minimize bleeding. The serous membrane with the muscularis was cut lengthwise from the posterior uterus to the anterior vagina (about $3 \mathrm{~cm}$ long), care being taken to avoid injury to the mucosa. This was then separated from the former layer through the incision by using fine scissors and forceps, and a loop of vaginal $S$ unfolded as shown in Pl. 1, Fig. 1. A segment of the uterovaginal junction including a part of the uterus and vagina, about 2 to $2.5 \mathrm{~cm}$ long, was cut off (Pl. 1, Fig. 2). The cut ends of the duct were first sutured together by 20 or more interrupted sutures with fine surgical thread (J.I.S. No. 2, hard type), care being taken not to make a knot in the lumen. After the end-to-end anastomosis, the serous membrane with the muscularis was then sutured (Pl. 1, Fig. 3), followed by removal of the thread placed on the uterus. After the operation, it was necessary to penetrate the anastomosed place with the forefinger through the cloaca and manipulate the finger in such a manner to extend or widen the lumen periodically until the egg was palpated in the uterus, since this place tended to diminish the diameter of the lumen with the progress of healing. Only hard-shelled eggs laid from 2nd through 22 nd day following intravaginal A.I. were incubated for examination.

Incubation of spermatozoa and infundibular tissue containing spermatozoa in plasma media at $41^{\circ} \mathrm{C}$

Three or four hours after asceptical injection of germ-free vasa semen into the magnum as. 
described by the preceding method, the middle portion of the infundibulum was isolated and cut into approximately $2 \times 2 \mathrm{~mm}$ or $4 \times 4 \mathrm{~mm}$ pieces in a petri dish with a small amount of Ringer's solution containing antibiotics in the same amounts as added to the phosphate buffer. About $0.3 \mathrm{~m} l$ of rooster's blood plasma, $0.6 \mathrm{~m} l$ of the Ringer's solution and $0.1 \mathrm{~m} l$ of embryo extract obtained from 9-day incubated fowl eggs were pipetted into a Carrel flask $(3.5 \mathrm{~cm}$ in diameter) and allowed to spread over the entire bottom (see CAMERON, 1950 $0^{1}$ ). Three fragments of the tissue or $0.1 \mathrm{~m} l$ of the vasa semen were then quickly introduced into the flask. After coagulation of the medium, $1 \mathrm{~m} l$ of Ringer's solution containing antibiotics and $0.4 \%$ fructose was added on top of the clot, after which the flask was stoppered with a rubber stopper, and incubated at $41^{\circ} \mathrm{C}$. For comparison a liquid plasma medium with the same components as above, except with $0.2 \%$ heparin added to the Ringer's solution prior to mixing with the blood plasma and embryo extract, was also tested.

After 1 or 2 days of incubation, the fragment of the tissue or desired amount of the clot containing spermatozoa in the flask was taken out, placed in one drop of phosphate buffer on a cover glass and teared or smashed into small bits with a couple of fine forceps for discharge of spermatozoa which was subjected to microscopic examination at about $37^{\circ} \mathrm{C}$.

\section{Results}

Maintenance of fertilizing spermatozoa in various regions of the oviduct

As shown in Table 1, incubation of spermatozoa in the anterior oviduct of the yearling hens for 2 days following ligation of the posterior isthmus had no detrimental effect in fertility, whereas vaginal deposition of semen immediately after ligation or sham-operation resulted in lowered fertility. Five out of the six sham-operated hens laid 15 eggs during the first week following A.I. and only 3 eggs were fertile. In addition all of those five hens expelled softshelled egg shortly after A.I.

Table 1. Fertility of spermatozoa following 2 days of incubation in the anterior and posterior oviduct (yearling hen)

\begin{tabular}{|c|c|c|c|c|c|c|}
\hline \multirow{2}{*}{ Ligation site } & \multirow{2}{*}{$\begin{array}{l}\text { Deposition } \\
\text { site }\end{array}$} & \multirow{2}{*}{$\begin{array}{c}\text { Total No. } \\
\text { hens }\end{array}$} & \multirow{2}{*}{$\begin{array}{l}\text { No. hens } \\
\text { expelled } \\
\text { soft egg }\end{array}$} & \multicolumn{3}{|c|}{ Percentage of fertility ${ }^{c}$} \\
\hline & & & & 1st week & 2nd week & 3rd week \\
\hline $\begin{array}{l}\text { Posterior end of } \\
\text { isthmus }\end{array}$ & Magnum & 6 & 5 & $\begin{array}{l}100 \\
(4)\end{array}$ & $\begin{array}{l}75.0 \\
(4)\end{array}$ & $\begin{array}{l}12.5 \\
(8)\end{array}$ \\
\hline $\begin{array}{l}\text { Posterior end of } \\
\text { isthmus }\end{array}$ & Vagina $^{a}$ & 10 & 5 & $\begin{array}{l}25.0 \\
(4)\end{array}$ & $\begin{array}{l}10.5 \\
(19)\end{array}$ & $\stackrel{0}{(13)}$ \\
\hline Sham-operation & Vagina $^{t}$ & 6 & 5 & $\begin{array}{l}20.0 \\
(15)\end{array}$ & $\begin{array}{c}4.2 \\
(24)\end{array}$ & $\begin{array}{l}0 \\
(20)\end{array}$ \\
\hline Intact & Vagina & 6 & 0 & $\begin{array}{l}83.3 \\
(30)\end{array}$ & $\begin{array}{l}25.0 \\
(24)\end{array}$ & $\begin{array}{l}0 \\
(19)\end{array}$ \\
\hline
\end{tabular}

a Semen was deposited immediately after individual operation

$b$ Number of hens that expelled soft-shelled egg shortiy after deposition of semen

$c$ Figures in parentheses show numbers of eggs

A similar experiment, with four hens, except that semen was injected into the anterior end of the uterus following ligation of the isthmus, gave normal fertility, $100 \%$ ( 8 eggs) in eggs laid during the first week and $31.3 \%$ (16 eggs) during the second week respectively, although all of these hens expelled soft-shelled eggs shortly after A.I. Such abnormal oviposition of soft-shelled eggs generally occured within 1 hour after operation. 


\section{TANAKA $\cdot$ KOGA}

When pullets were employed instead of yearling hens and semen introduced vaginally about 1 hour after ligation of the isthmus and sham-operation, an improved fertility was obtained as shown in Table 2. In this case seven out of twenty-five hens had expelled softshelled egg before A.I., one sham-operated hen expelled soft-shelled egg shortly, after A.I. and the remainder laid normal eggs on the day after operation.

Table 2. Fertility of spermatozoa following 2 days of incubation in the anterior and posterior oviduct (pullet)

\begin{tabular}{|c|c|c|c|c|c|}
\hline \multirow{2}{*}{ Ligation site } & \multirow{2}{*}{$\begin{array}{l}\text { Deposition } \\
\text { site }\end{array}$} & \multirow{2}{*}{$\begin{array}{l}\text { Total No. } \\
\text { hens }\end{array}$} & \multicolumn{3}{|c|}{ Percentage of fertility ${ }^{b}$} \\
\hline & & & lst week & 2nd week & 3rd week \\
\hline $\begin{array}{l}\text { Posterior end of } \\
\text { isthmus }\end{array}$ & Magnum & 14 & $\begin{array}{l}81.5 \\
(27)\end{array}$ & $\begin{array}{l}93.3 \\
(45)\end{array}$ & $\begin{array}{l}33.5 \\
(62)\end{array}$ \\
\hline $\begin{array}{l}\text { Posterior end of } \\
\text { isthmus }\end{array}$ & Vagina $^{a}$ & 19 & $\begin{array}{l}81.5 \\
(27)\end{array}$ & $\begin{array}{l}18.2 \\
(54)\end{array}$ & $\begin{array}{c}0 \\
(57)\end{array}$ \\
\hline Sham-operation & Vagina ${ }^{\sigma}$ & 6 & $\begin{array}{l}72.4 \\
(29)\end{array}$ & $\begin{array}{l}30.9 \\
(33)\end{array}$ & $\stackrel{0}{(35)}$ \\
\hline Intact & Vagina & 12 & $\begin{array}{l}95.7 \\
(69)\end{array}$ & $\begin{array}{l}39.7 \\
(67)\end{array}$ & $\begin{array}{c}0 \\
(69)\end{array}$ \\
\hline
\end{tabular}

a Semen was deposited about 1 hour after operation

$b$ Figures in parentheses show numbers of eggs

When the anterior end of the magnum was ligated and semen deposited into the infundibulum, eggs laid during three weeks after removal of the thread showed a comparable fertility pattern (Table 3) to those previously reported for intrainfundibular A.I. (TAKEDA, 1966201; TAKEDA, 196721). In contrast the incubation of spermatozoa in a segment ligated on the anterior magnum and the posterior isthmus resulted in lowered fertility as compared to those of sham-operated and intact groups.

Table 3. Fertility of spermatozoa following 2 days of incubation in the anterior oviduct

\begin{tabular}{|c|c|c|c|c|c|}
\hline \multirow{2}{*}{$\begin{array}{l}\text { Ligation } \\
\text { site }\end{array}$} & \multirow{2}{*}{$\begin{array}{l}\text { Deposition } \\
\text { site }\end{array}$} & \multirow{2}{*}{$\begin{array}{c}\text { Total No. } \\
\text { hens }\end{array}$} & \multicolumn{3}{|c|}{ Percentage of fertility ${ }^{a}$} \\
\hline & & & Ist week & 2nd week & 3rd week \\
\hline $\begin{array}{l}\text { Anterior end of } \\
\text { magnum }\end{array}$ & Infundibulum & 7 & $\begin{array}{l}100 \\
(14)\end{array}$ & $\begin{array}{l}86.7 \\
(15)\end{array}$ & $\begin{array}{l}37.5 \\
(16)\end{array}$ \\
\hline $\begin{array}{l}\text { Anterior end of } \\
\text { magnum and } \\
\text { posterior end } \\
\text { of isthmus }\end{array}$ & $\begin{array}{l}\text { Posterior } \\
\text { magnum }\end{array}$ & 24 & $\begin{array}{r}16.7 \\
(6)\end{array}$ & $\begin{array}{c}0 \\
(29) \\
.\end{array}$ & $\begin{array}{l}0 \\
(38)\end{array}$ \\
\hline Sham-operation & Vagina & 5 & $\begin{array}{l}93.1 \\
(29)\end{array}$ & $\begin{array}{l}24.2 \\
(33)\end{array}$ & $\begin{array}{l}0 \\
(32)\end{array}$ \\
\hline Intact & Vagina & 12 & $\begin{array}{l}93.3 \\
(60)\end{array}$ & $\begin{array}{l}32.8 \\
(67)\end{array}$ & $\begin{array}{l}0 \\
(58)\end{array}$ \\
\hline
\end{tabular}

a Figures in parentheses show numbers of eggs

Further experiment was carried out in relation to the maintenance of fertilizing spermatozoa in various regions of the oviduct below the isthmus. In preliminary studies in this laboratory, ligation of the posterior oviduct by short segment, such as ligations on the posterior isthmus and uterus, caused a secretion of oviduct fluid into the lumen in considerable amount during 
Maintenance of spermatozoa in hen's oviduct

the ligation period ( 2 days). This abnormal condition of the oviduct was not observed when a longer segment of the oviduct was ligated as conducted in the present experiments.

The results, shown in Table 4, indicate that the incubation of spermatozoa in a segment ligated on the posterior magnum and posterior uterus had an adverse effect on fertility. When the posterior uterus was ligated and semen deposited into the vagina, eggs laid during the first week following removal of the ligature showed $79.2 \%$ fertility, whereas incubation of spermatozoa in the segment lower than the anterior vagina resulted in destroyed fertilizing ability of the spermatozoa. The results in Table 2 through Table 4 are summarized diagrammatically in Text-fig. 1 .

Table 4. Fertility of spermatozoa following 2 days of incubation in various regions of the oviduct

\begin{tabular}{|c|c|c|c|c|c|}
\hline \multirow{2}{*}{ Ligation site } & \multirow{2}{*}{ Deposition site } & \multirow{2}{*}{$\begin{array}{c}\text { Total No. } \\
\text { hens }\end{array}$} & \multicolumn{3}{|c|}{ Percentage of fertility ${ }^{a}$} \\
\hline & & & 1st week & 2nd week & 3rd week \\
\hline $\begin{array}{l}\text { Posterior } \\
\text { magnum and } \\
\text { uterus }\end{array}$ & Isthmus & 24 & $\begin{array}{l}14.3 \\
(7)^{3}\end{array}$ & $\begin{array}{l}0 \\
(60)\end{array}$ & $\begin{array}{c}0 \\
(83)\end{array}$ \\
\hline Intact & Vagina & 14 & $\begin{array}{l}87.1 \\
(70)\end{array}$ & $\begin{array}{l}30.1 \\
(73)\end{array}$ & $\begin{array}{l}1.4 \\
(72)\end{array}$ \\
\hline Posterior uterus & Vagina & 20 & $\begin{array}{l}79.2 \\
(24)\end{array}$ & $\begin{array}{l}13.4 \\
(67)\end{array}$ & $\begin{array}{c}2.9 \\
(102)\end{array}$ \\
\hline Intact & Vagina & 15 & $\begin{array}{l}96.3 \\
(81)\end{array}$ & $\begin{array}{l}55.7 \\
(88)\end{array}$ & $\begin{array}{c}3.2 \\
(95)\end{array}$ \\
\hline Anterior vagina & Vagina & 31 & $\begin{array}{l}0 \\
(19)\end{array}$ & $\begin{array}{l}0 \\
(104)\end{array}$ & $\stackrel{0}{(116)}$ \\
\hline Intact & Vagina & 31 & $\begin{array}{l}95.0 \\
(161)\end{array}$ & $\begin{array}{l}39.1 \\
(156)\end{array}$ & $\begin{array}{c}3.3 \\
(150)\end{array}$ \\
\hline
\end{tabular}

a Figures in parentbeses show numbers of eggs

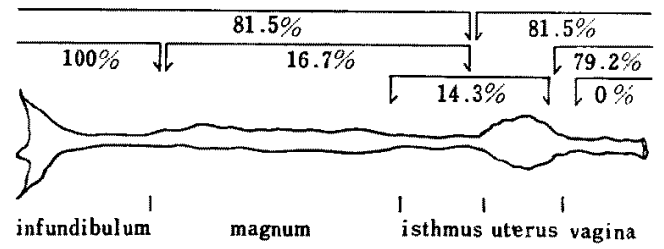

Text-Fig. 1. Extended oviduct, showing the regions referred to in the text where spermatozoa were incubated for 2 days. Arrows indicate the sites of ligation and figures show the first week fertility following the incubation in each region represented by closed lines $(-\sqrt{ }, \sqrt{ }$ or $\sqrt{ }+\sqrt{l})$

Relations of fertility and early embryonic mortality with site of A.I. and resection of uterovaginal junction

Table 5 shows fertility and early embryonic mortality, following intramagnal and intravaginal A.I., summarized from four replicated experiments with varying number of hens inseminated in each replicate. As expected, fertility was more persistent in hens subjected to intramagnal A.I. as compared to the intravaginal route. The percentage of early embryonic mortality in eggs laid during the first week following intramagnal and intravaginal 
A.I. respectively were $20.4 \%$ and $6.0 \%$ (significant at 0.05 level), while in the second week this tended to decrease with the former route $(12.4 \%)$ but was almost same level with the latter route $(8.8 \%)$. In the subsequent third week, early mortality increased with both routes. However, 4 yolks out of 10 soft-shelled eggs expelled by injection of posterior pituitary extract, which had been ovulated shortly after intramagnal A.I., were found to be broken in the course of egg formation (see PI, 1, Fig. 4 and Fig. 5). On the other hand, 4 blastodiscs out of 14 soft-shelled eggs obtained from the uterus on the day and the next day of intramagnal A.I. showed apparent abnormal cleavage after application of Kosin's method (KosIN, 1944 ${ }^{10)}$ ).

Table 5. Fertility and embryonic mortality in incubated eggs laid during 3 weeks following intravaginal and intramagnal A.I.

\begin{tabular}{|c|c|c|c|c|c|c|}
\hline \multirow{3}{*}{ Week } & \multicolumn{6}{|c|}{ Site of A.I. } \\
\hline & \multicolumn{3}{|c|}{ Vagina $^{a}$} & \multicolumn{3}{|c|}{ Magnum $^{a}$} \\
\hline & No. eggs & $\begin{array}{c}\text { Fertility } \\
(\%)\end{array}$ & $\begin{array}{c}\text { Embryonic } \\
\text { mortality } \\
(\%)\end{array}$ & No. eggs & $\begin{array}{l}\text { Fertility } \\
(\%)\end{array}$ & $\begin{array}{c}\text { Embryonic } \\
\text { mortality } \\
(\%)\end{array}$ \\
\hline lst week & 100 & 84.0 & 6.0 & 107 & 86.9 & $20.4^{b}$ \\
\hline 2nd week & 115 & 29.6 & 8.8 & 126 & 96.0 & 12.4 \\
\hline 3rd week & 104 & 5.8 & 50.0 & 129 & 72.1 & 30.1 \\
\hline
\end{tabular}

$a$ Total numbers of 23 and 33 hens were used for intravaginal and intramagnal A.I., respectively

$b$ There was a significant difference $(0.05$ level) in the first week mortality between the two routes of A.I.

Table 6. Fertility and embryonic mortality in incubated eggs laid during 3 weeks following intravaginal and intramagnal A.I. of germ-free semen

\begin{tabular}{|c|c|c|c|c|c|c|}
\hline \multirow{3}{*}{ Week } & \multicolumn{6}{|c|}{ Site of A.I. } \\
\hline & \multicolumn{3}{|c|}{ Vagina $^{a}$} & \multicolumn{3}{|c|}{ Magnum $^{a}$} \\
\hline & No. eggs & $\begin{array}{l}\text { Fertility } \\
(\%)\end{array}$ & $\begin{array}{c}\text { Embryonic } \\
\text { mortality } \\
(\%)\end{array}$ & No. eggs & $\begin{array}{c}\text { Fertility } \\
(\%)\end{array}$ & $\begin{array}{c}\text { Embryonic } \\
\text { mortality } \\
(\%)\end{array}$ \\
\hline 1st week & 131 & 13.0 & 11.8 & 100 & 92.0 & 10.9 \\
\hline 2nd week & 134 & 4.5 & 33.0 & 120 & 83.3 & 10.0 \\
\hline 3 rd week & 121 & 0.8 & 0 & 112 & 50.0 & 26.8 \\
\hline
\end{tabular}

a Total numbers of 30 and 24 hens were used for intravaginal and intramagnal A.I., respectively

Table 6 shows fertility and early embryonic mortality, following intramagnal and intravaginal A.I. of germ-free semen, summarized from four replicated experiments. Appreciable fertility patterns were obtained following intramagnal A.I., comparable to those obtained here for intramagnal A.I. of ejaculated semen, while the intravaginal route resulted in very poor fertility. On the other hand, no difference in early mortality of incubated eggs laid during the first week following A.I. was observed between the two routes but in the second week the intravaginal route led to higher mortality, although the differences in percentage of embryonic death between the two routes are certainly not significant in view of the small number of fertilized eggs obtained by intravaginal A.I.

Another trial was made to investigate the role of uterovaginal junction, for which seventeen hens were subjected to the resection of the uterovaginal junction. Twelve out of this number started egg production about 2 to 4 weeks after the resection, of which ten continued to lay eggs with varying mixed rates of soft- and hard-shelled eggs and two continued to lay only 
soft-shelled eggs, and five ceased egg production throughout the experimental period. The majority of hard-shelled eggs laid by the junction-resected hens appeared brittle; the average shell thickness of 15 incubated eggs (nine measurements for each egg) drawn by random sampling from those eggs used for the examination was $0.25 \mathrm{~mm}$.

Fertility and early embryonic mortality following intravaginal A.I. are shown in Table 7, summarized from five replicated experiments. Eggs from the junction-resected hens showed comparable fertility patterns to those from the control; the difference observed on eggs laid during the furst week ( $95.3 \%$ versus $86.3 \%$ ) was well within the range of normal sampling variation. In contrast, resection of the uterovaginal junction resulted in marked increase of early mortality throughout the designated period as compared to the control. P1. 1, Fig. 6 shows the interior appearance of the regions of the uterus and vagina isolated from a junctionresected hen, compared to the normal laying hen.

Table 7. Effect of resection of uterovaginal junction on fertility and embryonic mortality in incubated eggs laid following intravaginal A.I.

\begin{tabular}{|c|c|c|c|c|c|c|}
\hline \multirow{3}{*}{ Week } & \multicolumn{6}{|c|}{ Fertility and embryonic mortality } \\
\hline & \multicolumn{3}{|c|}{ Control (intact) } & \multicolumn{3}{|c|}{ Resection of uterovaginal junction ${ }^{a}$} \\
\hline & No. eggs & $\begin{array}{c}\text { Fertility } \\
(\%)\end{array}$ & $\begin{array}{c}\text { Embryonic } \\
\text { mortality } \\
(\%)\end{array}$ & No. eggs & $\begin{array}{c}\text { Fertility } \\
(\%)\end{array}$ & $\begin{array}{c}\text { Embryonic } \\
\text { mortality } \\
(\%)\end{array}$ \\
\hline 1st week & 127 & 95.3 & 2.5 & 54 & 86.5 & $37.8^{b}$ \\
\hline 2nd week & 131 & 61.8 & 2.5 & 50 & 50.0 & $28.0^{b}$ \\
\hline 3rd week & 115 & 10.4 & 16.7 & 53 & 15.1 & 37.5 \\
\hline
\end{tabular}

a A total number of 25 hens were inseminated and only hard-shelled eggs laid were incubated

$b$ There were significant differences $(0.01$ level) in mortality between the control and treatment

Daily variation in early embryonic mortality has been calculated from the original data in Table 5 through Table 7 and is presented graphically in Text-fig. 2, in which a group of intravaginal A.I. sited in Table 6 is omitted because of the small number of fertile eggs obtained. Each value for the vaginal route is presented in the average of 107 hens including those used for experiments in Table 5 and Table 7. High embryonic mortalities are shown on the second day after intramagnal A.I. in both ejaculated and germ-free semen groups, followed by a considerable decrease on the third day. Thereafter, these mortality rates are maintained as a relatively low level for approximately subsequent one and half weeks with some variation.

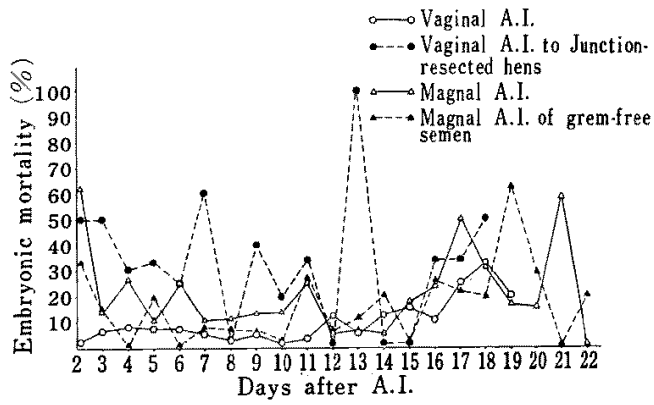

Text-Fig. 2. Daily variation in early embrionic mortality of incubated eggs laid following a single A.I. 


\section{TANAKA $\cdot$ KoGA}

Table 8. Explantation of infundibular tissue containing spermatozoa and incubation of vasa semen in plasma media or Ringer's solution at $41^{\circ} \mathrm{C}$

\begin{tabular}{|c|c|c|c|c|c|c|c|}
\hline \multirow{2}{*}{ Phase } & \multirow{2}{*}{ Media } & \multirow{2}{*}{$\begin{array}{c}\text { Test } \\
\text { material }\end{array}$} & \multirow{2}{*}{$\begin{array}{l}\text { Approx. } \\
\text { size of } \\
\text { tissue } \\
(\mathrm{mm} \times \mathrm{mm})\end{array}$} & \multirow{2}{*}{ Inca. day } & \multirow{2}{*}{ No. trial $^{b}$} & \multicolumn{2}{|c|}{$\begin{array}{l}\text { Flagellation activity } \\
\text { after incubation }\end{array}$} \\
\hline & & & & & & $\begin{array}{l}\text { Cilliated } \\
\text { cells }\end{array}$ & $\begin{array}{l}\text { Sperma- } \\
\text { tozoa }\end{array}$ \\
\hline \multirow{4}{*}{ Clot } & \multirow{4}{*}{$\begin{array}{l}\text { Plasma } \\
\text { medium }\end{array}$} & \multirow{3}{*}{$\begin{array}{l}\text { Infundibular } \\
\text { tissue }^{a}\end{array}$} & $2 \times 2$ & 1 & 3 & $+\sim+++$ & 2 \\
\hline & & & $2 \times 2$ & 2 & 3 & + & 1 \\
\hline & & & $4 \times 4$ & 1 & 2 & - & 0 \\
\hline & & 'Vasa semen & - & 1 & 3 & & 0 \\
\hline \multirow{3}{*}{ Liquid } & \multirow{2}{*}{$\begin{array}{l}\text { Heparin } \\
\text { plasma } \\
\text { medium }\end{array}$} & $\left\{\begin{array}{l}\text { Infundibular } \\
\text { tissue }^{a}\end{array}\right.$ & $2 \times 2$ & 1 & 2 & $+\sim+++$ & 2 \\
\hline & & 'Vasa semen & - & 1 & 3 & & 0 \\
\hline & $\begin{array}{l}\text { Ringer's } \\
\text { solution }\end{array}$ & Vasa semen & - & 1 & 3 & & 0 \\
\hline
\end{tabular}

a The infundibular tissue contains vas deferens spermatozoa

$b$ A single trial represents three Carrel flasks, each of which contains three fragments of the infundibular tissue

c Flagellation activities of ciliated cells and spermatozoa were expressed by relative values of - to +++ and 0 to 3 respectively, +++ and 3 representing maximum activity

In contrast, it is shown that high incidence of early mortality is distributed throughout the fertile period following intravaginal A.I. to the junction-resected hens, although much daily variation is seen. Also, the embryonic mortality has generally been seen to increase sharply in eggs laid toward the end of the fertile period.

Cultivation of infundibular tissue and incubation of spermatozoa in plasma media

As a means to investigate the physiological function of infundibular tissue in the maintenance of spermatozoa, the application of plasma culture method was tried. Microscopic observations on the activity of ciliated cells and spermatozoa after 1 or 2 days of incubation at $41^{\circ} \mathrm{C}$ are summarized in Table 8 . Both ciliated cells and spermatozoa discharged from the tissue fragments $(2 \times 2 \mathrm{~mm})$ after 1 day of incubation under the clot or liquid state of the plasma medium showed active flagellation, while a prolonged incubation (2 days) resulted in reduced activity with both types of cells. When a large fragment of the tissue $(4 \times 4 \mathrm{~mm})$ was employed, no flagellation was observed on either of them after 1 day of incubation. Under the conditions of this experiment it was also noted that there was a tendency to show a positive correlation between flagellation activity of ciliated cells and spermatozoa after incubation. No motile spermatozoa discharged from the tissue fragments with inactive ciliated cells, such as from a large fragment $(4 \times 4 \mathrm{~mm})$ incubated, were observed. In contrast, the incubation of vasa semen mixed with any of the media cited in Table 8 led to a complete immotility of spermatozoa within 1 day.

\section{Discussion}

There is evidence that if the oviposition of soft-shelled egg, as caused by the operation, occurs shortly after the deposition of semen into the vagina, fertility in eggs laid subsequently is affected adversely. In this connection, it was confirmed through studies in this laboratory (TANAKA and OKANo, 197122) that expulsion of either soft-or hard-shelled egg in the uterus by injection of posterior pituitary extract shortly after intravaginal A.I. to normal hens caused a marked reduction in fertility. 
Accordingly, in order to avoid this adverse effect on fertility, vaginal deposition of semen in those experiments which are summarized in Table 2 and Table 3 was carried out about 1 hour after operation since the oviposition of soft-shelled egg, if any, generally occurs within 1 hour after operation. This technique seemed to be much successful when young hens in active egg production were used. The egg production, however, during the first week was as strikingly reduced by ligation on the oviduct, especially by ligation on two places of the oviduct simultaneously, although this retarded egg production was considerably recovered by the third week in general.

Correctively, it was concluded that the regions of the infundibulum and uterovaginal junction are the most superior places for the maintenance of fertilizing spermatozoa than other regions of the oviduct (see Text-fig. 1). This agreed with previous investigators (FUJII and

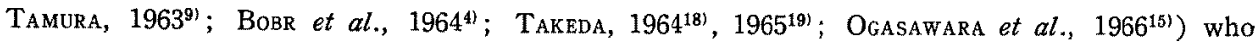
studied on the residence sites for spermatozoa in the hen's oviduct.

WENTWORTH and MELlen (1964) ${ }^{26}$ found that the intraperitoneal A.I. leads to a high incidence of embryonic mortality, $20.4 \%$, after 7 days of incubation. In the present experiment, however, those observations as shown in Table 5 are in general agreement with VAN KREY et $a l .(1966)^{24}$ and Lorenz and Ogasawara $(1968)^{11}$ although marked reduction of egg production after intramagnal A.I., reported by these authors, was not observed. They suggested two hypotheses in relation to the high incidence of early mortality in eggs laid during the first week following deposition of semen into the anterior oviduct, one of which involves the possible existence of a "sperm-selection mechanism", operating in the uterovaginal junction but not in the infundibulum, and another is the possible occurence of excessive polyspermy.

It is noteworthy that the embryonic mortality in eggs laid during the first week following intramagnal A.I. showed fairly lower value with the use of germ-free semen than that of ejaculated semen. The former mortality, however, seemed to be still high in contrast to that by intravaginal A.I. of ejaculated semen, although in consideration of immature vas deferens spermatozoa (see Munro, 1935 ${ }^{13)}$ ) the difference in mortality between the two routes of A.I. might be regarded as negligible. Accordingly, it is suggested that by intramagnal A.I. a large number of microorganisms which are inevitably introduced into the anterior oviduct with semen obtained by the massage method would adversely affect the development of the blastodisc. In a previous paper reported by OLSEN and NeHer $(1948)^{16}$ it was shown that a high embryonic mortality occurs with eggs laid on the day after transplantation of ova from the ovaries of non-mated donors into artificially inseminated hosts and they postulated that infection of the ova is the chief cause of this mortality. However, a rapid increase in early mortality toward the end of the fertile period is probably caused by the staleness of the spermatozoa. In early works a rapid reduction of hatchability which occurs approximately after two weeks following copulation has been reported by CREW (1926) ${ }^{8)}$ and WARREN and KILPATRICK $(1929)^{25)}$. In this respect Nalbandov and CARD (1943) ${ }^{14)}$ presented extensive experimental evidence, agreed with their observations and suggested that physiological changes in the spermatozoa permit it to retain its ability to fertilize the egg but zygotes produced by stale spermatozoa show a greater tendency to die sometime prior to hatching than do eggs fertilized by fresh spermatozoa. On the other hand, WILcox (1960) ${ }^{28)}$ found a tendency for the hatchability of eggs from the semen stored in vitro to be lower than that of eggs from fresh semen, but no numerical data are given in his paper.

A reduction in shell thickness of eggs laid by the junction-resected hens may have been 
caused by the removal of a part of the uterus including the mucosa, since a similar result has been reported by Asmundson and Jervis $(1933)^{2)}$. On the other hand, eggs laid by junctionresected hens following intravaginal A.I. showed nearly normal fertility patterns but significantly increased mortality, suggesting that uterovaginal junction plays a role of reducing the incidence of embryonic mortality after normal A.I. and that under removal of uterovaginal junction considerable numbers of spermatozoa ascend the oviduct following intravaginal A.I. and are subsequently maintained in the infundibular portion where they are responsible for the continued fertilization of eggs, since in the present experiment it has been proved that any regions of the oviduct, except the uterovaginal junction and infundibulum, are inadequate place for the maintenance of fertilizing spermatozoa.

Accordingly, the physiological and structual conditions in the posterior oviduct may be such as to restrict the number of spermatozoa reaching the site of fertilization, as operated in the cervix of certain mammals (BtsHop, 1961 ${ }^{3}$ ), and to prevent the abnormal or less active spermatozoa and other intruders including microorganisms since it has been demonstrated that powdered charcoal (Mimura, 1939'12) or dead spermatozoa (AlLEN and GRIGG, 1957"1) are unable to traverse the uterovaginal junction if they are deposited into vagina.

Weighing the facts obtained from A.I. of germ-free semen and A.I. to junction-resected hens, it might be suggested that a high incidence of the first week mortality after intramagnal A.I. involves many complicated factors, such as frequent occurence of excessive polyspermy, introduction of large numbers of abnormal spermatozoa and microorganisms.

In the final experiment a successful explantation of infundibular tissue containing spermatozoa suggests that further development of this technique would contribute to investigating the mechanisms by which spermatozoa are maintained for long periods in the glands and released for fertilization of ova, since it is considerably difficult to control the environmental factors in vivo, such as body temperature, participation of various humoral substances including hormones, etc.

\section{Summary}

Fertilizing ability of spermatozoa incubated for 2 days in various regions of ligated oviduct, the role of uterovaginal junction and culture of infundibular tissue containing spermatozoa in the domestic fowl were investigated.

In our studies we proved that both the uterovaginal junction and the infundibulum were the most superior places for the maintenance of fertilizing spermatozoa than other regions of the oviduct. Intramagnal insemination led to a high incidence of early mortality. Whereas deposition of germ-free vas deferens semen by the same route resulted in reduced mortality, this tendency was still high in contrast to the intravaginal insemination of ejaculated semen. On the other hand, resection of uterovaginal junction following intravaginal insemination resulted in nearly normal fertility but in marked increase of early mortality throughout the designated period. Consequently, it is suggested that microbial contamination of the oviduct may be one of the factors causing a high incidence of the first week mortality following intramagnal insemination and that uterovaginal junction may have a screening effect against such intruders.

It was demonstrated that motile spermatozoa can be maintained in vitro for at least 2 days at $41^{\circ} \mathrm{C}$ if the fresh infundibular tissue containing spermatozoa is cultured in plasma medium. 
Maintenance of spermatozoa in hen's oviduct
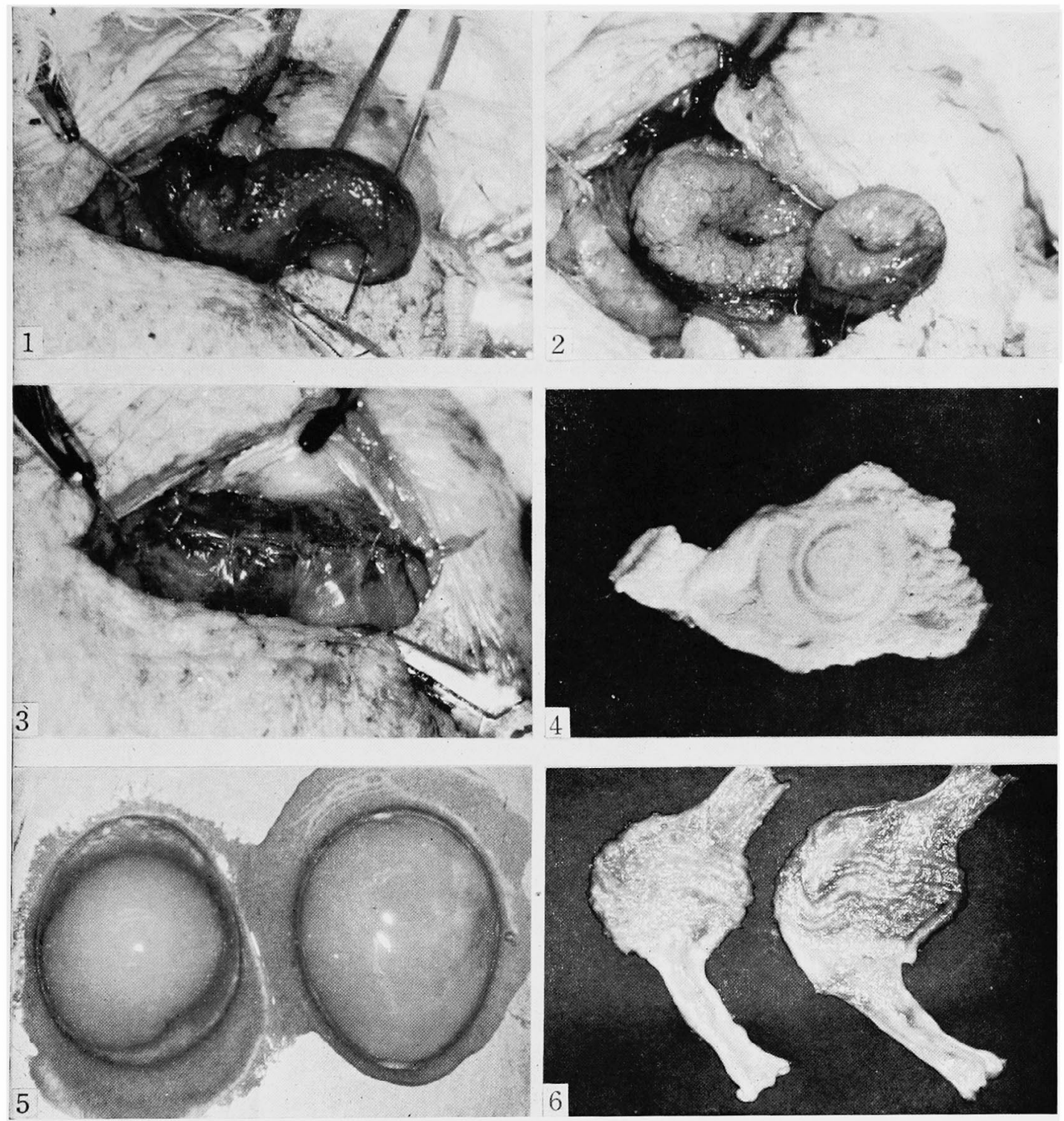

EXPLANATION OF PLATE 1

Fig. 1. Unfolded vaginal $\mathrm{S}$ and a part of the posterior uterus, separated from the serous membrane with the mascularis

Fig. 2. Cut ends of the duct after removal of the uterovaginal junction including a part of the uterus and vagina

Fig. 3. Closed serous membrane after end-to-end anastomosis of the duct

Fig. 4. Broken yolk surrounded spirally with albumen, found in the posterior magnum following intramagnal A.I. before ovulation

Fig. 5. Opened soft-shelled egg (left) obtained from the uterus on the day of intramagnal A.I. just before ovulation and opened hard-shelled egg (right) laid on the next day of the same treatment. Note the broken yolk surrounded with albumen in both cases

Fig. 6. Interior appearance of the uterus and vagina. Left picture shows the oviduct of the junction-resected hen that has continued a mixed laying of soft-shelled and hard-shelled eggs, and right indicates the same region in the normal laying hen 


\section{References}

1) Allen, T.E. and C.W. Grigg (1957) Aust. J. Agric. Res., 8: 788-799.

2) Asmundson, V.S. and J.G. Jervis (1933) J. Expt. Zool., 65: 395-420.

3) Bishop, D.W. (1961) In : Sex and Internal Secretion. 3 rd edn. Vol. II. p. 707. Ed. W.C. Young. Williams \& Wilkins, Baltimore.

4) Bobr, L.W., F.W. Lorenz and F.X. Ogasawara (1964) J. Reprod. Fert., 8: 39-47.

5) Bobr, L.W., F.X. Ogasawara and F.W. Loremz (1964) J. Reprod. Fert., 8: 49-58.

6) Bogdonoff, P.D., Jr., and C.S. Shaffner (1954) Poultry Sci., 33: 665-669.

7) Cameron, G. (1950) Tissue Culture Technique. 2 nd edn, Academic Press Inc., New York.

8) CRew, F.A.E. (1926) Proc. Roy. Soc. Edin., 46: 230-238.

9) Fujn, S., and T. Tamura (1963) J. Fac. Fish. Anim. Husb. Hiroshima Univ., 5: 145-163.

10) Kosin, I.L. (1944) Poultry Sci., 23: 266-269.

11) Lorenz, F.W. and F.X. Ogasawara (1968) J. Reprod. Fert., 16: 445-455.

12) Mrmura, H. (1939) Okajimas Folia Anat. Jap., 17: 459-476.

13) Munro, S.S. (1935) Proc. Soc. Expt. Biol. Med., 33: 255-257.

14) Nalbandov, A. and L.E. Card (1943) Poultry Sci., 22: 218-226.

15) Ogasawara, F.X., F.W. Lorenz and L.W. Bobr (1966) J. Reprod. Fert., 11: 33-41.

16) Olsen, M.W. and B.H. Neher (1948) J. Expt. Zool., 109: 355-366.

17) Parker, J.E., F.F. McKenzie and H.L. Kempster (1942) Missouri Agric. Expt. Sta. Res. Bul., 347: 1-50.

18) TAKedA, A. (1964) Jap. Poultry Sci., 1: 19-31.

19) TAKEdA, A. (1965) Jap. Poultry Sci., 2: 115-122.

20) Takeda, A. (1966) Jap. Poultry Sci., 3: 15-22.

21) TAKEDA, A. (1967) Jap. Poultry Sci., 4: 62-67.

22) Tanaka, K. and K. Okano (1971) Sci. Bul. Fac. Agric. Kyushu Univ., 25: 97-102.

23) Van Drimmelen, G.C. (1946) J.S. Afr. Vet. Med. Ass., 17: 43-52.

24) Van Krex, H.P., F.X. Ogasawara and F.W. Lorinz (1966) J. Reprod. Fert., 11: 257-262.

25) Warren, D.C. and L. Kilpatrick (1929) Poultry Sci., 8: 237-256.

26) Wentworth, B.C. and W.J. Mellen (1964) Brit. Poultry Sci., 5: 59-65.

27) Wilcox, F.H. and C.S. Shaffner (1958) Poultry Sci., 37: 1353-1357.

28) Wilcox, F.H. (1960) Poultry Sci., 39: 459-467. 


\title{
雌鶏卵管内における精子の受精能力保持に関する研究
}

\author{
田中耕作・古賀脩 \\ (九州大学農学部)
}

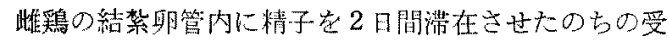
精能力の観測, 卵款腺部一胵移行部 (以下胵移行部) の 役割の追求，および組織堷溘法を用いることにより，卵 管各部位における精于の受精能力保持ならびに受精卵の 胚の早期死亡原因に関して研究念行なった。

その結果，精子の受精能力保持については，腟移行部 およびろ斗部が他の部位に比較してるっともすぐれてい ることが証明された，卵白分泌部に精液定注入すると，

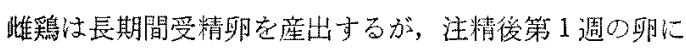
おける㗏の早期死亡率注高くなることが観測された。し かし、精管の後部加ら無菌的に採取した精液を卵白分泌 部内に注入した場合，受精率は前者とほとんど同じ值 示したか，脴の早期死亡率はかなり低下子ることが認め られた。産畉鶏の胵移行部老切除し，回復後胵部注精老

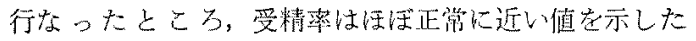
が，胚の早期死亡象については受粼卯の産出期間を通じ て非常に高い值が観測された。したがって，卵白分泌部 注精により脴の死亡等が高くなる原因の一つは, 注精時 細菌の混入によるすのと考えられる。一方，胵部注精の 場合，胵移行部はこのような細菌等が卵管上部に上昇才 ることを阻止䒚る役割を果しているものと推定された。

以上注生体内に予ける観察であるが，精子允含方乃斗 部組織の一部を体外に摘出し，組織培空法定用いて血獎 培地に移植すると，その培地は固形状执よび液状のいず れの場合も，組織内の精子は $41^{\circ} \mathrm{C}$ の高温下でるくなく

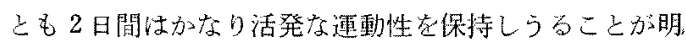
らかとなった。 